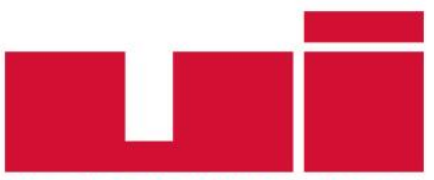

ULLUSLARARASIILIȘKiLER

Akademik Dergi

Yayın ilkeleri, izinler ve abonelik hakkında ayrıntılı bilgi:

E-mail: bilgi@uidergisi.com.tr

Web: www.uidergisi.com.tr

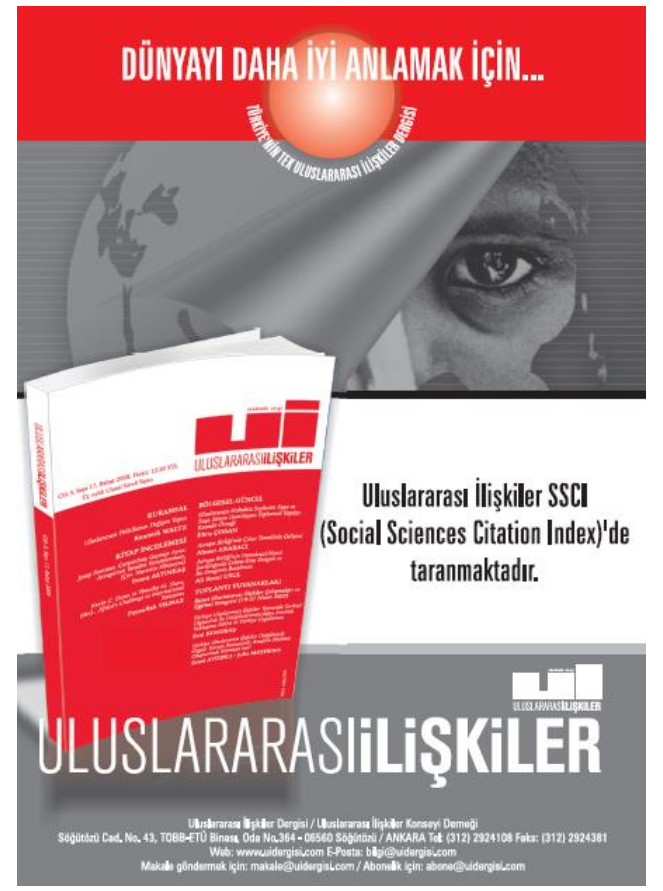

Paris İklim Anlaşmasına Teorik Yaklaşım: Neo-Neo Tartışması, Eko-Marksizm ve Yeşil Kapitalizm

\author{
H. Akın ÜNVER* \\ * Yrd. Doç. Dr., Uluslararası İlişkiler Bölümü, Kadir \\ Has Üniversitesi
}

Bu makaleye atıf icin: Ünver, H. Akın, "Paris İklim Anlaşmasına Teorik Yaklaşım: Neo-Neo Tartışması, Eko-Marksizm ve Yeşil Kapitalizm“, Uluslararası İlişkiler, Cilt 14, Sayı 54, 2017, s. 3-19.

Bu makalenin tüm hakları Uluslararası İlişkiler Konseyi Derneği'ne aittir. Önceden yazılı izin alınmadan hiç bir iletişim, kopyalama ya da yayın sistemi kullanılarak yeniden yayımlanamaz, çoğaltılamaz, dağıtılamaz, satılamaz veya herhangi bir şekilde kamunun ücretli/ücretsiz kullanımına sunulamaz. Akademik ve haber amaçlı kısa alıntılar bu kuralın dışındadır.

Aksi belirtilmediği sürece Uluslararası Illişkiler'de yayınlanan yazılarda belirtilen fikirler yalnızca yazarına/yazarlarına aittir. UİK Derneğini, editörleri ve diğer yazarları bağlamaz. 


\title{
Paris İklim Anlaşmasına Teorik Yaklaşım: Neo-Neo Tartışması, Eko-Marksizm ve Yeşil Kapitalizm
}

\author{
H. Akın ÜNVER \\ Yrd. Doç. Dr., Uluslararası İlişkiler Bölümü, İİBF, Kadir Has Üniversitesi, İstanbul. \\ E-posta: akin.unver@khas.edu.tr
}

\section{ÖZET}

Uluslararası iklim müzakerelerinde uzun yıllardır baş gösteren uyuşmazlıklar, uluslararası ilişkiler akademik ve bilimsel araştırmalarının ilgi odağı olmuştur. Bu çalışmalarda ekseriyetle, işbirliğini destekleyici ve bedavacılığı önleyici yeni müzakere ve dengeleme mekanizmaları geliştirerek, uluslararası güç eşitsizliklerini iklim konusunda birleştirmesinin yolları aranmıştır. Bu makale, ilk olarak 1997 Kyoto Anlaşması’nı takiben yapılan iklim müzakerelerinin neden başarısızlığa uğradığını ve bu başarısızlıkların 2015 Paris İklim Anlaşması ile nasıl çözülebildiğini neorealist ve neoliberal bağlam içerisinde konumlandırmaktadır. Özellikle enerji güvenliğinin sistemsel anarşi, özyardım ve göreli çıkar tespitlerine, neoliberal kurumsalcılı̆̆ın verdiği kompleks çoklu-bağımlılık ve mutlak çıkar cevapları, iklim müzakerelerinin başarısı hakkında teorik bir cevap vermektedir. Makale, neo-neo tartışması kadar, iki yeni sistemsel teorik yaklaşımı da (Eko-Marksizm ve Yeşil Kapitalizm) karşılaştırmakta, bu sayede karbon salınımı ve iklim konularında cereyan eden önemli bir teorik tartışmayı, uluslararası ilişkiler literatürü içinde konumlandırmaya çalışmaktadır.

Anahtar Kelimeler: İklim ve Çevre Politikası, Neorealizm, Neoliberal Kurumsalcılık, Eko-Marksizm, Yeşil Kapitalizm

\section{IR Theoretical Approach to the Paris Climate Agreement: Neo-Neo Debate, Eco-Marxism and Green Capitalism}

\begin{abstract}
Continued inability of the international climate negotiations to reach a common resolution has been subject to academic and scientific research focus. These studies have focused on the ways of fostering cooperation and preventing free-riding in climate negotiations, through the development of balancing methods. This article first attempts to explore why climate negotiations since 1997 Kyoto Protocol have failed and how such failures could be overcome in 2015 Paris UN Climate Conference through a neorealist and neoliberal institutionalist context. Especially, neorealist concepts such as systemic anarchy, self-helf and relative gains, along with the neoliberal institutionalist response to them through complex interdependence and abolute gains, have been instrumental to crafting a theoretical answer to the success of most recent climate negotiations. The article then adds two new systemic-theoretical approach to the debate, namely Eco-Marxism and Green Capitalism, and aims to contextualize these approaches within international relations theoretical literature.
\end{abstract}

Keywords: Climate and Environmental Policy, Neorealism, Neoliberal Institutionalism, Eco-Marxism, Green Capitalism. 


\section{Giriş}

Uluslararası toplum, Paris İklim Anlaşması'na kadarki yirmi yılı aşkın sürede, devam eden müzakerelere rağmen küresel ısınmaya dönük yapıcı bir anlaşmaya varamamışı. 1992 Rio Dünya Zirvesi ile başlayan karbon salınımını ve küresel ısınmayı azaltmayı hedefleyen süreç, 1997 Kyoto Protokolü ile en önemli adımını atmasına rağmen, yasal olarak bağlayıcı bir karbon salınımı rejimine uzun süre evirilememiştir. Son olarak 30 Kasım-12 Aralık 2015 tarihlerinde Paris’te yapılan Birleşmiş Milletler İklim Değişikliği Konferansı (UNFCCC) ise, uzun yıllar boyunca varılamayan karbon salınımını azaltma oranlarında tarihi bir uzlaşmaya sahne olmuştur. Kyoto Protokolü'nün aksine, Paris İklim Anlaşması'nın en önemli özelliği, tepeden dikte edilen salınım hedefleri yerine, aşağıdan yukarı hareket eden ve ülkelerin kendi salınım azaltma oranlarını kendilerinin belirlediği bir girişim olmasıdır. ${ }^{1}$ İklim konusunda meydana gelen bu önemli diplomatik ilerleme, müzakerelerin geçmiş başarısızlığının nasıl aşılabildiği konusunda da önemli soruları beraberinde getirmektedir.

İklim değişikliği, uluslararası sistemin çözüm üretemediği tek siyaset alanı değildir. Giderek artan eleştiriler, küresel rejimin finansal regülasyondan ${ }^{2}$ silahsızlanmaya ${ }^{3}$, kamu sağlığından ${ }^{4}$ donmuş çatışmaların sonlandırılmasına ${ }^{5}$ kadar geniş bir yelpazede sorunlara çözüm üretemediğini belirtmektedir. Uluslararası müzakerelerde doğal kaynakların kullanımı, kıtlık, ekosistem bozulması ve atık idaresi gibi alanlarda da istenilen düzeyde işbirliği sağlanamamıştır. ${ }^{6} \mathrm{Bu}$ boyutta küresel bir çevre krizi, uluslararası ilişkiler teorisinin temel kavramları olan hayatta kalma (survival), özyardım (selfhelp) ve milli çıkar konularında hayati yeni soruları gündeme getirmiş, antroposen olarak adlandırılan, beşeri aktivitelerin, doğal aktivitelere kıyasla daha fazla (ve olumsuz yönde) dünyayı etkilediği bir dönemi yaratmıştır. ${ }^{7}$ Antroposen döneminin getireceği uzun vadeli yaşayış ve kaynak sorunları, artık uluslararası müzakerelere farklı bir bakış açısı getirilmesini gerektirmiş, devletlerin hayatta kalmaları için gerekli kabul edilen kriterlerin bir revizyonu ihtiyacını beraberinde getirmiştir. Zira çevre ve küresel ısınma konuları, uluslararası ilişkiler açısından yapısal birer tehlike olmasına karşın, devletin savunma kapasitesinin ana unsuru olan silahlı kuvvetler veya caydırıcılık ile de çözülmesi imkânsızdır. $\mathrm{Bu}$ açıdan uluslararası ilişkilerde ana eksende tartışılan tehdit, hayatta kalma ve özyardım gibi konular, çevre ve iklim konularında klasik parametreler etrafında çözülememekte, yeni vizyon ve yaklaşımları gerekli kılmaktadır.

İklim değişikliğinin iktisadi ve sosyal hayata etkilerinin bilimsel çalışmalara yansıması ilk olarak 1960’larda başlamış, konunun temel kavramsallaştırması Erlich, Hardin, Kennan, Meadows

1 Adil Najam, “10 tests to find out if Paris's climate change deal is a success”, The Guardian, 7 Eylül 2015, http://www.theguardian. $\mathrm{com} /$ commentisfree/2015/dec/07/paris-climate-change-deal-summit-guide (Erişim Tarihi 26 Haziran 2016).

2 Marcelo Madueira Prates, "Why Prudential Regulation Will Fail to Prevent Financial Crises. A Legal Approach", Working Paper 335, Banco Central Do Brasil, 2013, http://www.bcb.gov.br/pec/wps/ingl/wps335.pdf, (Erişim Tarihi 26 Haziran 2016).

3 "The Global Nuclear Nonproliferation Regime", Council on Foreign Relations, 25 Haziran 2013, http://www.cfr.org/ nonproliferation-arms-control-and-disarmament/global-nuclear-nonproliferation-regime/p18984, (Erişim Tarihi 26 Haziran 2016).

4 "Ebola: the failures of the international outbreak response", Medecins Sans Frontiers, 27 Ağustos 2014, http://www.msf. org/article/ebola-failures-international-outbreak-response, (Erişim Tarihi 26 Haziran 2016).

5 Mykola Kapitonenko, “Resolving Post-Soviet 'Frozen Conflicts': Is Regional Integration Helpful?”, Caucasian Review of International Affairs, Cilt 3, No.1, Kış 2009, s.37-44.

6 Suzan Ilcan, “Global Governing Organizations: Order-Building and Waste Management", Current Sociology, Cilt 54, No.6, Kasım 2006, s.851-872.

7 Will Steffen, Paul J. Crutzen ve John R. McNeill, “The Anthropocene: Are Humans Now Overwhelming the Great Forces of Nature", AMBIO: A Journal of the Human Environment, Cilt 36, No.8, 2007, s.614-621. 
et.al. ve Catton ile tamamlanmıştır. ${ }^{8}$ Takiben, uluslararası ilişkilerde çevre sorunlarının güvenlik sorunu olarak ortaya konuşu Westing, Gleick, Homer-Dixon, Orme ve Barnett ile devam etmiştir. ${ }^{9}$ $\mathrm{Bu}$ ana tartışmanın uluslararası ilişkiler teorisi içerisindeki yansımaları ise iki ana kol üzerinden devam etmiştir. Bunların ilki, uluslararası müzakereler ${ }^{10}$, ikincisi de uluslararası rejim ve sistem ${ }^{11}$ üzerinden yürüyen literatürdür.

Neo-neo tartışması, uluslararası ilişkiler disiplininin temel tartışmalarından birisidir. $\mathrm{Bu}$ tartışmanın kutuplarından herhangi birisine meyil gösteren araştırmacıların yanı sıra ${ }^{12}$, bu iki kutbun harmanlanması veya birleştirilmesine yönelik fikirler de mevcuttur (neo-neo sentezi). ${ }^{13}$ Bunların ötesinde tartışmanın, aslında teoriyi yeterince ilerletmediğine ve marjinalize edilmesi gerektiğine dönükfikirler de mevcuttur. ${ }^{14}$ Bu makale, teorikaçıdan neo-neo tartışmasının disipline olan etkilerinden ziyade, bu tartışmanın iklim güvenliği ve işbirliği alanına yaptığı katkılar üzerinde duracaktır. Zira bu makale, neo-neo tartışmasının özellikle iklim konusunda yeni bir teorik açılım sağlayabileceğini, bu alanda yapacağı katkının klasik kullanım alanından daha büyük bir etki yaratabileceğini önermektedir.

Uluslararası sistemin ve anlaşmazlık-işbirliği dinamiklerinin çözümlenmesi konularına neorealizm ve neoliberalizm farklı yaklaşır. Örneğin Waltz, uluslararası ilişkilerin temel dinamiğini küresel anarşi sisteminde arar ve rasyonel aktörlerin ana amacını bu anarşi sisteminde hayatta kalma olarak belirler. ${ }^{15} \mathrm{Bu}$ açıdan Waltz’a göre çatışma, güç ve çıkar gibi değişkenler, uluslararası sistemin yapısına (tek-iki-çok kutupluluk ve anarşi) bağlıdır. Bu yapı, Walt’a göre uluslar-üstü bir idari otoritenin olmadığı küresel sistemde, devletlerin dengeleme, sürüye uyum (bandwagoning) ve caydırıcılık üzerinden büyük ölçekli çatışmaları engelleyebileceği tek metottur. ${ }^{16}$ Neoliberal kurumsalcılık ise anarşinin yanı sıra, karşılıklı bağımlılık ilkesini de yapısal bir faktör olarak kabul ederek, ülkelerin anlaşma ve işbirliği yoluyla sistemsel anarşiye karşı mücadele edebileceklerini belirtir. ${ }^{17} \mathrm{Bu}$ bağlamda neoliberal kurumsalcılık, kurumlar ve işbirliğini kuvvetlendirici diğer yapıların, realist okulun ana

8 Paul Ehrlich, "The Population Bomb”, New York Times, 4 Kasim 1970, s.47; Garrett Hardin, "The Tragedy of the Commons”, Science, Cilt 162, No.3859, 1968, s.1243-1248; George F. Kennan, “To Prevent a World Wasteland”, Foreign Affairs, Cilt 48, Nisan 1970, s.401-413; Donella H. Meadows, Jorgen Randers, Dennis L. Meadows, Beyond the Limits: Confronting Global Collapse, Envisioning a Sustainable Future, Chelsea Green Publishing Company, 1993; William R. Catton, Overshoot: The Ecological Basis of Revolutionary Change, University of Illinois Press, 1982.

9 Arthur H. Westing (der), Cultural Norms, War and the Environment, Oxford University Press, 1988; Peter H. Gleick, (der), Water in Crisis: A Guide to the World's Fresh Water Resources, Oxford University Press, 1993; Thomas HomerDixon, "On the Environmental Changes as Causes of Acute Conflict", International Security, Cilt 16, No.2, Sonbahar 1991; John Orme, "The utility of force in a world of scarcity”, International Security, Cilt 22, No.3, 1997, s.138-167; Jon Barnett, "Security and Climate Change", Global Environmental Change, Cilt 13, No.1, 2003, s.7-17.

10 Peter M. Haas, Robert O. Keohane ve Marc A. Levy (der), Institutions for the Earth Sources of Effective International Environmental Protection, MIT Press, 1993; Lawrence E. Susskind ve Saleem H. Ali, Environmental Diplomacy: Negotiating More Effective Global Agreements, Oxford University Press, 2014; Farhana Yamin ve Joanna Depledge, The International Climate Change Regime A Guide to Rules, Institutions and Procedures, Cambridge University Press, 2004.

11 John Ruggie, "Multilateralism: The Anatomy of an Institution”, International Organization, Cilt 46, No.3, 1992; Stephen D. Krasner, Structural Conflict: The Third World Against Global Liberalism, University of California Press, 1985; Robert O. Keohane, After Hegemony: Cooperation and Discord in the World Political Economy, Princeton University Press, 1984; Bruce M. Russett, International Regions and the International System: A study in political ecology, Rand McNally, 1967.

12 Robert Keohane (der.), Neorealism and its Critics, New York, Columbia University Press, 1986 veya Kenneth Waltz'ın aynı derlemedeki "Reflections on Theory and International Politics: A Response to My Critics" başlıklı bölümü, s. 330

13 Ole Waever, "Rise and Fall of the Inter-Paradigm Debate", Steve Smith, Ken Booth ve Marysia Zalewski (der), International Theory: Positivism and Beyond, Cambridge, Cambridge University Press, 1996, s.151-154.

14 Robert M.A. Crawford, Idealism and Realism in International Relations, New York, Routledge, 2001.

15 Kenneth Waltz, "Realist Thought and Neorealist Theory", Journal of International Affairs, Cilt 44, No.1, 1990, s.21-37.

16 Stephen M. Walt, Origins of Alliances, Ithaca, Cornell University Press, 1987. 1, 2 ve 5. bölümler.

17 Robert O. Keohane ve Joseph S. Nye Jr., Power and Interdependence, Londra, Longman Classics, 2011. 
parametreleri olan kuvvet dengesi ve çıkar gibi olgulara kıyasla daha faydalı olabileceği görüşündedir. Sonuç itibariyle neo-neo tartışması, sistemsel anarşinin öncül şart (antecedent condition) olarak kabul edildiği ve bu öncül şarta karşı caydırıcılık - göreli çıkar veya karşılıklı bağımlılık - mutlak çıkar ekseninde iki ayrı cevabın verildiği bir tartışmadır.

Lipson, anarşi kavramının, uluslararası ilişkilerin "Rosetta Taşı” olduğunu önermiş, hem neorealizm hem de neoliberal kurumsalcılığın çıkış noktasının yapısal bir anarşi endişesi olduğunu öne sürmüştür. ${ }^{18}$ Daha soyut düzeyde neorealistler, uluslararası sistemde devlet-üstü (ya da devletleri idare edecek küresel-meşru bir yapı) olmadığı için sistemin nizamdan uzak olmasını, savaş ve anlaşmazlığın kalıcı bir sebebi olarak öngörürler. Anarşinin tam olarak nasıl tanımlandığı ve işlevselleştirildiği ise ayrı bir tartışma konusudur. Milner, anarşi kavramı ile ilgili iki ayrı anlamın (nizam eksikliği, idare eksikliği) kullanıldığını, ancak pratikte bu kavramların uygulama sorunu çıkardıklarını belirtmektedir. ${ }^{19}$ Örneğin, uluslararası sistemde devletler üstü bir idare yapısının olmaması, sistemin kendi içsel nizamı ve kurallarının olmadığı anlamına gelir mi? Zira her ne kadar realist alt teoriler anarşinin bir kurum, norm ve kültür eksikliği olduğunu belirtse de, çatışma ve savaş sırasında cereyan eden ve iki muharip tarafın da kabul edip benimsediği askeri norm, kurum ve kültürlerin nasıl ortaya çıktığını açıklayamaz. Hedley Bull'un uluslararası toplum kavramsallaştırması, aslında tam da bu anlamda sistemin kendine özel çerçeveleri, kuralları ve gelenekleri olduğunu iddia etmektedir. ${ }^{20}$ Entegre ve sürekli norm ve kurum algıları, uluslararası sistemin bahsedildiği gibi anarşik olmadığını, anarşi algısının devletleri belli tipte çatışma-odaklı reflekslere ittiğini önermektedir. Oye de bu kavramsallaştırma üzerinden uluslararası sistemde siyasal idare dışında da kültürel ve tarihsel yapıların önemli ölçüde anarşiyi engellediğini belirtmiştir. ${ }^{21}$ Hatta Milner, neorealist çerçeve içerisinde sık kullanılan kuvvetler dengesi ve karş1-dengeleme reflekslerinin bile birer nizam unsuru olduğunu öne sürmüştür. ${ }^{22}$

İkinci olarak, uluslararası sisteme hükümet etmenin ne anlama geldiği de bir soru işaretidir. Waltz’a göre, Weberyen bir devletin olmaması, uluslararası sistemde meşru şiddet ve güç kullanımını olanaksız hale getirmektedir. ${ }^{23}$ Neoliberal kurumsalcıllğa göre ise bu tip bir dünya hükümetinin olmaması, uluslararası anlaşmaları bağlayıcı hale getirecek yasal bir mekanizmanın eksikliğidir. ${ }^{24}$ $\mathrm{Bu}$ açıdan neorealistlerin küresel idare anlayışı kuvvet kullanımı, neoliberal kurumsalcıların anlayışı ise anlaşma bağlayıcılı̆̆ı (ekseriyetle iktisadi hukuk) üzerine odaklanmaktadır. Dahası, anarşinin "uluslararası sistemin belirleyici faktörü" olduğu savı da pratikte problemlidir. Devletleri çatışmaya sürükleyen faktörün anarşiden ziyade kurumsallaşmış ve yapısal hale gelmiş çıkar algıları ve hesapları olduğuna dönük de bir karşı-argüman üretilebilir. Mutlak anarşik bir küresel sistemde, devletlerin çatışma ve savaş için kullandığı sinyalleme, çıkar tespiti, seferberlik ve ikmal gibi yüksek oranda kompleks ve tarihsel kurum-pratiklerine bağlı fonksiyonları da gerçekleştirmesi beklenemez. Alexander Wendt' in meşhur "anarşinin, devletlerin onunla ne yaptığına bağlı olduğu" ${ }^{25}$ gözlemi, bu konuda hala en önemli eleştirilerden birisidir.

18 Charles Lipson, "International Cooperation in Economic and Security Affairs", World Politics, Cilt 37, 1984, s.1-23.

19 Helen Milner, "The assumption of anarchy in international relations theory: A critique”, Review of International Studies, Cilt 17, 1991, s.67-85.

20 Hedley Bull, The Anarchical Society: A Study of Order in World Politics, London, Macmillan, 1977.

21 Kenneth Oye, "Explaining Cooperation under Anarchy: Hypotheses and Strategies”, World Politics, Cilt 38, No.198, s.16-18.

22 Milner, "The Assumption of Anarchy", s.77.

23 Waltz, "Realist Thought and Neorealist Theory", s.30.

24 Keohane ve Nye, Power and Interdependence, s.23.

25 Alexander Wendt, "Anarchy is what States Make of it: The Social Construction of Power Politics", International Organization, Cilt 46, Sayı 2, 1992, s.391-425. 
Bu teorik arka plan, neo-neo tartışmasının ana parametreleridir. Makale, bu tartışmanın ötesine geçerek, neo-neo tartışmasının enerji güvenliği ve özellikle iklim müzakereleri konusuna getirdiği yeniliklerle ilgilenmektedir. Zira yine bu makale, neo-neo tartışmasının, klasik parametrelerinden ziyade iklim, enerji ve çevre konularına daha büyük katkı yaptığını düşünmektedir. Devletlerin, çıkarlarını özyardım kavramının getirdiği güç maksimizasyonu ve güvenlik ikilemi gibi unsurlarla elde etmek yerine işbirliğini tercih etmeleri nasıl sağlanabilir? Uluslararası sistem, ne gibi durumlarda çıkarların çatışma veya özyardım değil de kolektif hareket ve müzakere ile elde edilmesine evirilebilir? $\mathrm{Bu}$ sorular, uzun süredir karbon salınımı ile ilgili beklenen uzlaşmaya varamayan devletlerin, Paris İklim Anlaşması'nda hangi yollarla anlaşabildikleri konusunda önemli ipuçları vermektedir.

\section{Neorealist Bağlam}

Enerji ve karbon salınımı konularında kuvvetler dengesi ve kabiliyet gibi konular, konvansiyonel realist parametrelerin köşe taşı olmuş askeri ve jeopolitik ölçümler ile değil, gayrisafi milli hâsıla (GSMH), endüstriyel üretim ve iktisadi büyüme gibi kavramlarla hesaplanır. ${ }^{26}$ Zira karbon salınımı, enerji tüketiminin bir sonucu, bu da ülkelerin enerji kaynağı tüketerek yaptıkları üretim ve tüketim faaliyetlerinin bir bütünüdür. Dolayısı ile bir ülkenin karbon salınımını düşürmesi, ya o ülkenin daha az enerji tüketmesine (ve dolayısıyla daha az üretim-tüketim yapmasına) veya aynı ülkenin daha verimli enerji iletim ve/veya filtreleme mekanizmaları geliştirerek, üretime ayıracakları kaynakları verimliliğe kaydırmalarışeklinde düşünülmektedir. Alternatifbir yol olarak da bu ülkelerin yüksek karbon salınımlı fosil yakıtlarından ziyade, temiz ve yenilenebilir enerji kaynaklarına doğru yönelmeleri düşünülebilir. Ancak bu alternatifte de ülkelerin, yeni enerji kaynak tiplerine göre bir altyapı oluşturmaları (tesis, istasyon, iletim ve yatırım) ve yine üretime aktarılabilecek parasal kaynaklarından feragat etmeleri düşünülmektedir. Bu bağlamda Kyoto Protokolü’nü başarısız (veya en azından büyük ülkeler nezdinde sonuçsuz) kılan faktörlerden biri de, salınım azaltılmasının dolaylı olarak ülkelerin sanayi üretimi ve büyüme oranlarını olumsuz etkilemesi ve küresel iktisadi güç maksimizasyonu (veya göreli kazançları) noktasında ortaya çıkan anlaşmazlıktır.

Christopher Napoli, oyun teorisi modellemeleri kullanarak, Kyoto Protokolü'nü sonuçsuz bırakan ana faktörlerin başında yapısal kuvvet dengelerinin (iktisadi büyüme yarışı) geldiğini iddia etmiştir. ${ }^{27}$ Buradan hareketle Napoli, ileriki bir tarihte yapılacak karbon salınımı ve iklim değişikliği konferanslarının bu yapısal - göreli kuvvet dengeleri gözettiği takdirde başarılı olacağını da eklemiştir. 2010 'da Oxford Üniversitesi ve London School of Economics'in ortaklaşa hazırladığı Hartwell Paper, Kyoto Protokolü’nün asıl yenilgisinin 2009 Kopenhag İklim Zirvesi ile belirlendiğini idda ederek uzun müzakerelerin "küresel ekonominin karbondan arındırılması" (yani fosil temelli yakıtların ana üretim ve büyüme kaynağı olarak azaltılması) konusunda başarısız olduğunu ortaya koymuştur. ${ }^{28}$ İktisadi noktada Nordhaus'un eleştirisi ise Kyoto rejiminin "yüksek maliyet, düşük getiri” üzerine kurulu olması ve bu sebeple de katılım teşvikinin düşük olmasıdır. ${ }^{29}$ Dolayısıyla neorealist bağlam,

26 Michael Grubb, Benito Müller ve Lucy Butler, "The Relationship between carbon dioxide emissions and economic growth”, Oxbridge Study on CO2-GDP Relationships, Oxford, Şubat 2012, https://www.oxfordenergy.org/wpcms/wpcontent/uploads/2011/02/Presentation19-The-RelationshipBetweenCarbonDioxideEmissionsandEconomicGrow th-MGrubbBMullerLButler-2004.pdf, (Erişim Tarihi 26 Haziran 2016).

27 Christopher Napoli, “Understanding Kyoto's Failure”, SAIS Review of International Affairs, Cilt 32, Say1 2, 2002, s.183-196.

28 Gwyn Prins et.al., The Hartwell Paper: A New Direction for Climate Policy After the Crash of 2009, Institute for Science, Innovation and Society, University of Oxford, Mayis 2010, http://eprints.lse.ac.uk/27939/1/HartwellPaper_English_ version.pdf, (Erişim Tarihi 26 Haziran 2016).

29 William D. Nordhaus ve G. Joseph, "Requiem for Kyoto: An Economic Analysis of the Kyoto Protocol." Yales Cowles Foundation Tartışma Bildirisi, Ekim 1998. 
iklim anlaşmalarının başarısızlığını, müzakerelerin içerisinde bulunan göreli kazanç ve ulusal çıkar kavramları ile açıklamakta, bu kazanç ve çıkar parametrelerinin göz ardı edilmesinin ise devamlı başarısızlığa yol açacağını belirtmektedir.

Bu açıdan Paris İklim Anlaşması'nı başarılı kılan husus, karbon salınımının iktisadi ve siyasi boyutunu, küresel güç dengesi bağlamında iyi konumlandırmış olmasıdır. Neorealist perspektife göre en büyük sistemsel farklılık, 1990'lar ile beraber büyük bir hızla büyümeye başlayan Çin'in, 2000’lerin sonuna doğru Amerika Birleşik Devletleri'ni karbon salınımı payında geride bırakarak birinci olması ve 2010'lar içerisinde de bu farkı giderek açması olmuştur. ${ }^{30}$ Her ne kadar bu salınım farkı Çin’i hem otomotiv, hem de çimento üretiminde dünya lideri yapmış olsa da, Çin hükümetleri, küresel karbon salınımının düşürülmesi konusunda liderlik yapma fikrini benimsemişlerdir. Bu siyasetin temel sebeplerinden bir tanesi Çin'in endüstri kentlerindeki hava kirliliği meselesinin iç politikadaki en önemli başlık haline gelmesidir. ${ }^{31}$ Çin'in UNFCCC nezdindeki müzakere pozisyonu, bunun bir tezahürü olarak 2009'dan itibaren değişmiş, salınım hedefleri daha gerçekçi ve sürdürülebilir bir şekilde Çin'in beş yıllık planlarına dâhil edilmiştir. ${ }^{32}$

$\mathrm{Bu}$ bağlamda belki de en yeni ve ilginç argüman, Robert Falkner'ın ortaya koyduğu ve iklim müzakerelerinin neorealizm açısından başarısını açıklayan "minilateralizm" kavramsallaştırmasıdır. ${ }^{33}$ Minilateralizm, küresel ısınmaya en çok katkısı olan ve dolayısıyla endüstri üretimi ve iktisadi büyümeleri en yüksek olan ülkelerin bir araya gelerek daha küçük ve elit bir platformda bu meseleyi çözmelerini öngörür. Bu açıdan Falkner, neorealizmin güç kutupları perspektifi üzerinden, karbon salınımı en yüksek (ve salınımı düşürmelerinin küresel açıdan olumlu etki yapacağı) ülkeleri, daha küçük, hızlı ve aktif bir müzakere kampının içine alarak, eski tip büyük ve kalabalık müzakere forumlarının hantallığını aşmayı önermektedir. Bu bir çok açıdan neorealizmin sistemsel anarşi, statüko, göreli kazanç ve güç maksimize eden aktörler kavramlarını da içeren bir tanımlamadır.

Küresel ısınma ve enerji güvenliği kavramları benzer bir anarşi algısından beslenir. Her iki kavramda da uluslarüstü meşru ve bağlayıcı bir idarenin eksikliği, ülkeleri enerji güvenliklerini sağlama konusunda bir tür özyardım rejimine iter. Bu şekilde düşünülmüş bir anarşi sistemi içerisinde devletler, sınırlı enerji kaynakları ve ekonomilerini idame ettirmek için birbiriyle rekabet içerisine girerler. Enerji kaynaklarının sadece özyardım ve rekabet ile elde edildiği bir uluslararası sistemde de küresel ısınma ve karbon salınımını azaltmaya yönelik telkinler, ülkeler tarafından ekonomik ve endüstriyel rekabeti engelleyici unsurlar olarak algılanarak bir nevi tehdit muamelesi görürler. Karbon salınımının azaltılmasına yönelik müdahaleler, özellikle gelişmekte olan ve gelişimlerini yüksek oranda fosil yakıtı tüketiminden sağlayan ülkeler için daha hayati bir hal almakta, bu ülkelerin salınım azaltma rejimlerine katılımlarını ve uyumlarını zorlaştırmaktadır. Bu da ülkelerin, iklim idaresine dönük yaklaşımlarını sıfır toplamlı bir oyun haline getirmekte, ülkelerin sürekli olarak sorumluluğu ve siyasi inisiyatifi başka ülkelere bırakmasına (buckpassing ${ }^{34}$ ) neden olmakta ve meseleyi çözmek yolunda sorumluluk almalarını zorlaştırmaktadır.

30 Zhu Liu, “China's Carbon Emissions Report 2015”, Harvard Befler Center Reports, Mayıs 2015, http://belfercenter.ksg. harvard.edu/publication/25417/chinas_carbon_emissions_report_2015.html, (Erişim Tarihi 26 Haziran 2016).

31 Ibid. s.18.

32 Ibid. s.22.

33 Robert Falkner, "A Minilateral Solution for Global Climate Change? On Bargaining Efficiency, Club Benefits and International Legitimacy", Perspectives on Politics, Cilt 14, Sayı 1, Mart 2016, s.87-101.

34 John Mearsheimer, The Tragedy of Great Power Politics, New York, W.W. Norton \& Company, 2001, s.160. 
Bu açılardan bakıldığında, 1990'lar ile başlayan iklim müzakerelerinin neden başarısızlıkla sonuçlandığını, uluslararası ilişkiler teorileri açısından en iyi neorealizm açılamaktadır. Devletler, sistemsel anarşinin hüküm sürdügü bir dünyada, iktisadi büyüme ve enerji kaynaklarının temini devletler üstü bir otorite tarafından sağlanmadığı için, sürekli olarak kendi kaynaklarını kendileri yaratma veya tedarik etme zorunluluğu içerisindedirler. Bu zorunluluk, özellikle fosil yakıtları gibi sınırlı kaynakların temininde zaman zaman sıfır toplamlı bir mücadeleye sebep olmakta, küresel ısınma yerine enerji güvenliğinin asli unsur olarak belirlenmesine sebebiyet vermektedir. Tamamen realist bir perspektiften bakıldığında, devletin asli görevi enerji güvenliğini sağlamak, bu kaynakları kullanarak ekonomiyi ve büyümeyi idame ettirmek ve sonuç olarak GSMH ve üretim konularında göreli kazançlarını asgariye çıkarmaktır. Her ne kadar uzun vadede küresel ısınma da realist lügat tarafından kabul edilen tehdit unsurlarını (açlık, kuraklık, besin ve tarım güvenliği gibi) yaratsa da, devletler bununla ilgili sorumluluğu başka ülkelere devrederler (buckpassing). Özellikle iktisadi büyümeleri ve bunun tezahürü olan üretim, işsizlik, enflasyon gibi parametreleri fosil yakıtlarının tüketimine daha çok bağlı ülkeler, iklim rejimine katılım göstermemekte ve uluslararası müzakerelerin geniş oranda uyum ve uygulama sorunu yaratmaktadır.

\section{Neoliberal Kurumsalcı Bağlam}

Neorealist kuram, Paris İklim Anlaşması'na kadar uygulanan iklim rejimlerinin neden başarısız olduğunu çok iyi açıklamakta, ancak Paris İklim Anlaşmasının başarısını açıklayamamaktadır. Bunun başlıca sebebi realist düzlemin uluslararası anlaşmazlıklara dönük birincil mücadele mekanizmasının yeterlilikler ve caydırıcılık kavramları olmasıdır. İklim, çevre, karbon salınımı ve küresel ısınma kavramlarının hiçbiri bu iki kavram tarafından çözümlenememekte, dolayısıyla yeni çözüm kavramlarına ihtiyaç duyulmaktadır. Bu bağlamda Paris İklim Anlaşması'nı başarılı kılan kavramlar daha ziyade mutlak çıkar, çoklu kazanç, kompleks bağımlılık ve müzakerelerin kurumsallaşmasıdır.

Enerji güvenliği ve karbon salınımı, geleneksel uluslararası ilişkiler teorisinin ana hipotezi olan küresel anarşi yoluyla tanımlanabilir. Zira devletler üstü bir idarenin olmadığı bir enerji sisteminde devletler, kendi büyümeleri için gerekli enerji kaynaklarını özyardım yoluyla elde etmeli, enerji politikaları alanında hayatta kalmak için de gerekirse sıfır toplamlı anlaşmazlıklara girmelidir. $\mathrm{Bu}$ bağlamda enerji üreticileri pazar konusunda, enerji tüketicileri tedarik konusunda, enerji transit ülkeleri de jeopolitik önemleri konusunda güvenlik aramakta ve birbirleriyle rekabet içine girmektedirler. Neoliberal kurumsalcılık, küresel enerji anarşisinin sistemsel bir tehdit olduğunu kabul etse de, bunun doğrudan bir çatışmaya sebebiyet vereceği savını kabul etmez. ${ }^{35}$ Bunun yerine iktisat ve rasyonel aktör modellerini kullanarak karşılıklı bağımlılık, kurumlar oluşturma ve mutlak kazanç üzerinden enerji anarşisinin olumsuz etkilerini aşmaya çalışır. Bu bakımdan neoliberal kurumsalcılık, küresel enerji yönetişim rejiminin reformuna daha çok odaklanır ve enerji üretici-tüketici-transit ülkeler arasında daha sıkı bir karşılıklı bağımlılık ve mutlak kazanç sisteminin oluşturulmasını önceliklendirir. Göreli (neorealist) ve mutlak (neoliberal) kazanç kavramlarını tam da bu noktada, enerji ve iklim konularında tekrar değerlendirmek gerekmektedir. Realist perspektife göre kazanç, karşılaştırılacağı bir matris olmadığı takdirde bir şey ifade etmemektedir. Buna göre devletlerin neye göre ve ne kadar kazandığı önem taşımakta, kazancın kıyaslı olarak o ülkeyi, rekabet içinde olduğu diğer ülkeler arasında nereye konumlandırdığı hayati bir mesele haline gelmektedir.

35 Arthur A. Stein, "Neoliberal Institutionalism”, Christian Reus-Smit and Duncan Snidal (der), The Oxford Handbook on International Relations, New York, Oxford University Press, 2008, s.211. 
Neoliberal perspektife göre ise enerji ve iklim konularında göreli kazanç vizyonu, devletleri sürekli olarak tedarik ve pazar çatışmalarına ve anlaşmazlıklarına sürükleyen, sıfır toplam bakış açısıyla hem uzun vadede devletlerin işbirliğiyle kazanacakları enerji getirisini ortadan kaldıran, hem de sürekli anlaşmazlıklara sokarak enerji ithal ve ihraç risk faktörünü artıran bir kavramdır. Buna göre devletler, göreli kazanç hesapları içerisinde tekli kazanan ve çoklu kaybeden dengesine göre konumlarını belirleyecek, sistemsel anarşinin özyardım ve kuvvetler dengesi gibi özelliklerine karşı savunmasız kalacaklardır. Buna karşılık neoliberal kurumsalcılık, devletlerin mutlak kazançları takip eden kolektif siyaset içerisine girip, işbirliği içerisinde bulunan bütün ülkelerin kazançlı çıkmasını önermektedir. Oyun teorisi ve ekonometrik modeller üzerinden hesaplanan mutlak kazanç, işbirliği içerisine giren bütün ülkelere, girmeyen ülkelere kıyasla daha fazla getiri sağladığı için uzun vadede uyumu teşvik edici ve anarşinin olumsuz etkilerini asgariye indirici bir faktör olarak önerilmektedir. Bu bakımdan neoliberal kurumsal yaklaşımın, enerji güvenliğinin realist okumalarına dönük cevabı, Uluslararası Enerji Ajansı (International Energy Agency-IEA) veya OPEC gibi tedarik ve arzı kurumsallaştıran yapılardır. Bu yapıların amacı, anarşik bir küresel enerji sisteminde enerji üreticileri, tüketicileri ve transit ülkeler arasında iletişim sağlayarak öngörülebilirliği ve işbirliğini artırmaktır. Keza arz ve tedarik güvenliğini ve buna bağlı olarak fosil yakıtlarına bağlı büyümeyi kurumsal işbirliği üzerinden sağlayabilen bir uluslararası sistem, enerji tüketiminin yan etkileri olan iklim değişikliği ve karbon salınımı konularında da daha meşru ve inandırıcı bir görünüş sergileyebilir. Bir başka deyişle, iklim müzakerelerinin başarısının ön şartı, enerji güvenliğini sağlayacak mekanizmaların yaratılmasıdır.

Neoliberal kurumsalcı perspektifin enerji ve iklim çalışmalarına önemli bir diğer katkısı da Keohane ve Nye'ın geliştirdiği kompleks çoklu-bağımlılık kavramıdır (complex interdependence). ${ }^{36}$ Kompleks çoklu-bağımlılık, modern devletlerin farklı katmanlar üzerinde (devletler arası, devletler ötesi ve milletler ötesi) bağlantıları olduğunu, realist bakış açısında belirtildiği gibi güvenlik ve askeri meselelerin öncelikli gündem maddeleri olmadığını ve işbirliğinin, tam da bu güvenlik ve askeri meselelerin geri plana alınmasıyla gerçekleşebileceğini dile getirir. Keohane ve Nye’a göre çoklu bağımlılık, devletlerin işbirliği şansını daha geniş bir siyaset alanına yayarak, uyum ve birlikte hareket etme olasılığını artırarak anarşinin olumsuz yan etkilerini asgariye indiren bir başka metottur. $\mathrm{Bu}$ açıdan, enerji güvenliği ile ilgili farklı mekanizmaların (tedarik, talep, iletim, regülasyon) yürürlükte olması, ülkelerin işbirliği şanslarını artırmakta, bu işbirliğini iklim rejimi müzakerelerine de bir ivme olarak taşımaktadır. Bu kurumların ana amaçları, enerji ve çevre konularında kullanılabilir teknik bilgiye daha kolay erişim, bu konularda bağlayıcılığı bulunan alt kurumlar yaratma, enerji piyasasını ilgilendiren çok taraflı anlaşmaları müzakere etme ve son olarak çok sayıda devletin ortak (veya en azından birbiriyle uyumlu) bir enerji üretim, tüketim ve iletim politikalarını takip etmeleridir. Belki de en önemlisi, küresel ısınma konusu, ülkeleri dolaylı yoldan birbirlerine bağlayan yapısal faktörlerin en sistematiğidir.

Enerji siyasetinin realist gereksinimleri olan tedarik, iletim ve güvenlik konularında işbirliği, sonrasında gelecek olan iklim ve karbon salınımı müzakerelerinin altyapısını oluşturmaktadır. Zira Kyoto sonrası dönem bize şunu göstermiştir: fosil yakıtlarının ekonomik büyüme ve üretimle olan ilişkileri sağlamlaştırılmadan iklim ve çevre gibi konularda çok uluslu işbirliğini sağlamak imkânsızdır. Bunun sebebi ise enerji güvenliği konusunda hayatta kalma refleksi ile davranan hiçbir devlet salınım ve iklim konularında uyum göstermeye teşvik edilememesidir. Örneğin 2009 Kopenhag müzakerelerini başarısızlığa sürükleyen sebeplerin başında enerji güvenliği konusunda anlaşma olmaksızın salınımlar konusunda hedeflerin dayatılmasıdır. Bu sebeple Paris İklim Anlaşması́na

36 Keohane ve Nye, Power and Interdependence, s.28. 
giden yolda en önemli kolaylaştırıcı unsur, küresel enerji güvenliği konularının belli bir seviyede kurumsallaşması ve petrol fiyatlarının düşmesiyle birlikte uygun bir işbirliği rejimi oluşturmasıdır. Steven Krasner'ın, uluslararası kurumların ontolojisi ile ilgili yazısında altını çizdiği gibi, başarılı kurumsallaşma, aktörlerin beklentilerinin belli bir konu etrafında örtüşmesine yol açar. ${ }^{37}$ Dolayısıyla başarılı kurumsallaşma, çok sayıda uluslararası oyuncuyu iyi tanımlanmış ve uygulanabilir ortak siyaset paydasında buluşturabilmelidir. Bu açıdan, aktörlerin enerji güvenliği konusunda beklentileri büyük oranda örtüşürse, bir süre sonra bu uluslararası normlara evirilecek ve uluslararası bir rejim oluşturacaktır.

Ancak uluslararası normlar ve kurumlar, disiplindeki en eski tartışmalardan biri olan ulusal egemenlik konusunu gündeme getirmektedir. Zira hangi şartlar altında uluslararası iklim hedeflerinin ülkelerin iç işlerinde bağlayıcı olacağı konusu, devletler için güvenlik meselesi olarak algılanmaktadır. Zira modern egemenlik anlayışının temeli olan Westphalia tipi "devlet-odaklı bölgelendirme", milli çıkar ve iç işleri gibi hayati kavramların ana dayanağı olmuştur. ${ }^{38}$ Ancak iklim (hatta enerji) politikaları, küresel ve çok aktörlü doğaları gereği Westphalia tipi egemenlik anlayışına ciddi bir rekabet oluşturmaktadır. Sera gazı ve karbon salınımı gibi ölçümlerin ülkeler bazında yapılması, bu konuda düşülecek en büyük hatalardan biridir; zira bir ülkede artan salınım miktarı, o ülke ile sınırlı kalmayarak bütün küresel iklimi etkileyecektir. Bunun yanı sıra iklim müzakerelerinin de devletler tarafından yapılıyor olması, konunun küresel bir iklim güvenliği sorunundan, devletlere mahsus endüstri ve ekonomi güvenliği konusuna indirgenmesine yol açmaktadır.

İklim konusuna dönük bölgesel odak bozukluğu, hem ülkelerin konuyu tam olarak kavramsallaştırmalarına, hem de konunun çözümüne dönük siyaset geliştirmelerine engel olmuştur. Örneğin, karbon salınımını azaltmaya dönük sınırların belirlenmesi, bir devletçi proje halini almış, devletlerin birbirlerine veya uluslararası kuruluşlara karşı sorumluluğu noktasında çözümlenmiştir. Dolayısıyla, Çin'in 2009 Kopenhag İklim Konferansında, enerji verimliliğini artıcı önlemler konusunda dış gözlemcileri tamamen reddetmesi bu egemenlik ve bağımsızlık anlayışı üzerinden okunmalıdır. Öte yandan Çin'in bu tutumu da diğer ülkeler nezdinde rahatsızlığa yol açmış, Pekin'e karşı geniş çaplı bir güvensizliğe sebep olmuş ve müzakerelere dönük uyum sorunu yaratmıştır. Ancak asıl konu burada Çin’in veya dış gözlemcilerin güvenilir olması veya olmaması değil, devletçi perspektifin, küresel bir problemi çözme konusunda yetersiz kalmasıdır. Bu da uzun bir zaman dilimi içerisinde iklim müzakerelerinin neden karbon salınımını azaltma konusunda başarısız olduğunun açıklamalarından bir tanesidir. Sonuç olarak, başarılı olabilecek bir iklim anlaşması, hem devletlerin yerleşik Westphalia egemenliği reflekslerini aşacak, hem de karbon salınımı azaltılmasına dönük işbirliğinin devletler arası değil, tamamen küresel olduğunun idraki üzerinden ilerleyecektir.

Keza Stephen Krasner'ın tanımladığı şekilde rejim teorisi, kurumların uzun vadede devlet davranışını değiştirilebileceğinden ve anarşik bir sistem içerisinde de olsa belli prensipler, normlar ve kurallar üzerinden aynı siyasi karar etrafında kümelenebileceklerini öne sürmüştür. ${ }^{39} \mathrm{Bu}$ bakımdan neoliberalizm, kabiliyetler, çıkarlar ve sıfır toplamlı oyunlar gibi realist parametreleri bir kenara iterek tutsak ikileminin dışında bir model ortaya koymaya çalışmış, işbirliğine dönük siyasetin rasyonel karar verme modelleri içerisinde daha iyi konumlandırıldığını iddia etmiştir.

37 Stephen D. Krasner (der), International Regimes, Ithaca, Cornell University Press, 1983. s.57.

38 Saskia Sassen, "Territory and Territoriality in the Global Economy”, Journal of Human Values, Cilt 15, Sayı 2, Haziran 2000, s.372-393.

39 Krasner, International Regimes, s.38. 


\section{Neo-Neo Tartışması Ötesinde İklim Müzakereleri: Eko-Marksizm ve Yeşil Kapitalizm}

Her ne kadar küresel ısınma ve iklim değişikliği tartışmalarının çok öncesinde yaşamış olsa da, Karl Marx, kent ve kırsal arasındaki gelişmişlik farkının toprağı bozduğunu ve gübre ithalatının çiftçi sosyolojisini, kapitalizme bağlı hale getirdiğini öne sürerek çevre ile ilgili ilk sistemsel teoriyi ortaya koymuştur. ${ }^{40}$ Marx'tan çok sonra 1960 'larda Amadeo Bordiga, kapitalist endüstrileşme ve çevre faktörleri ile ilgili ilk geniş eleştirel literatürü oluşturmuştur. ${ }^{41} 1972$ 'de ise James O'Connor, kapitalizm ve çevre arasındaki ilişkinin "ikinci çelişki” (birincisi geleneksel Marksizm'deki üretim güçleri ve ilişkileridir) olduğunu ileri sürmüştür. ${ }^{42} \mathrm{Bu}$ bağlamda ilk çelişki nasıl sınıf çatışmalarını ortaya çıkardıysa, ikinci çelişki de çevresel hareketlerin ortaya çıkışıyla “doğanın başkaldırııı” ı ortaya çıkarmıştır. Klasik Marksizm’in, modern küresel iklim ile ilgili pozisyonu çok geliştirilmemiş olsa da, aynı teorik yol üzerinden devam eden "dünya sistem teorisi"43 bu konuya daha net bir yaklaşım sunmaktadır. Zira Wallerstein'ın kavramsallaştırması üzerinden gidersek, endüstrileşmiş ülkeler, küresel ısınmaya en çok katkıda bulunan aktörler olmasına karşın, iklim değişikliğine karşı gıda, ilaç ve barınma konularında da vatandaşlarına en çok imkânı sağlayabilecek pozisyondadır. Bunun tersine küresel ısınmaya katkısı en az olan ülkeler, hem iklim değişikliğinin etkilerini doğrudan hissedip, hem de vatandaşlarını bu etkilere karşı koruyabilecek altyapıdan yoksundurlar. Dolayısıyla devletlerin, küresel ısınmaya katkıları ve bunun sonucunda maruz kaldıkları mağduriyetler asimetriktir. Küresel ısınma ve iklim değişikliğine karşı Marksist eleştirilerin hem sınıf temelli, hem de sistemsel boyutlu olanları uzun süre neoliberal iktisadi model tarafından cevaplanamamış, kapitalizmin bu tip çevre olumsuzluklarını ortadan kaldırmaktan ziyade, bu olumsuzlukların görünen sonuçlarını (sağlık, kirlilik gibi) ortadan kaldırmaya dönük bir girişim içerisinde bulunduğu gözlemlenmiştir.

İleriki sayfalarda tartışacağımız üzere bir dizi sistemsel faktör, kapitalizmin içerisinden yeni bir akım olarak Yeşil Kapitalizm'in çıkışına yol açmış, Marksizm'in aksine kapitalizmi tamamen değiştirmekten ziyade, onun reformunu öngören bir yaklaşım olarak literatüre girmiştir. Örneğin Newell ve Paterson'un kritiğinde, kapitalizmin ana açmazının büyüme saplantısı olduğu, bu güdünün ötesine geçemeyen kapitalizmin kar ve büyümeyi fosil yakıtları dışındaki kaynaklara endekslemesi gerektiği belirtilmiştir. ${ }^{44}$ Her ne kadar bu yaklaşım çok yenilikçi olmasa da, kapitalizm ve küresel ısınma arasındaki korelasyonu yeniden düşünmesi açısından önemlidir. Newell ve Paterson, kapitalizm ve fosil yakıtları arasındaki bağlantı içerisindeki farklı çıkar gruplarını (enerji şirketleri, otomotiv üreticileri, elektrik üreticileri vb.) analiz etmiş, bu grupların çıkarlarını fosil yakıtlarından ayrıştırmak için öneriler sunmuştur. ${ }^{45} \mathrm{Bu}$ öneriler daha ziyade fosil yakıtlarının kullanımına ek vergilendirme ve cezai yaptırım üzerinden yaklaştığı için ise serbest piyasa iktisatçıları tarafından eleştirilmiştir. $\mathrm{Bu}$ bağlamda cezadan farklı olarak geliştirilen bir yaklaşım da yenilenebilir ve temiz enerjilerin verimli hale getirilmesine dönük yatırımların teşvikidir. Ancak yine serbest piyasaya dönük devlet müdahalesi içerdiği için bu yaklaşım da eleştirilmiştir.

40 John Bellamy Foster ve Fred Magdoff, “Liebig, Marx and the Depletion of Soil Fertility: Relevance for Today's Agriculture”, Monthly Review, Cilt 50, Say1 3, 1998, s.43-60.

41 Amadei Bordiga, “The human species and the Earth's crust”, Libcom, 15 Nisan 2012, https://libcom.org/library/ human-species-earths-crust-amadeo-bordiga, (Erişim Tarihi 26 Haziran 2016).

42 James O’Connor, “Capitalism, Nature, Socialism: A Theoretical Introduction”, Capitalism, Nature, Socialism. Cilt 1, Sayı 1, 1988, s.11-38.

43 Immanuel Wallerstein, “The West, Capitalism, and the Modern World-System”, Review, Cilt 15, Say1 4, 1992, s.561-619.

44 Peter Newell ve Matthew Paterson, Climate Capitalism: Global Warming and the Transformation of the Global Economy, Cambridge, Cambridge University Press, 2010.

45 Newell ve Paterson, Climate Capitalism, s.15. 
Eko-Marksizm'in ana eleştirisi, kapitalizmin sürekli büyümeye odaklı yapısıyken, Yeşil Kapitalizm, büyümenin kendisinden ziyade, onun fosil yakıtlarının tüketimine olan bağımlılığını problematize etmiştir. Bu sebeple Eko-Marksizm'in küresel ısınmaya karşı önlemi kapitalizmin kendisinin feshi iken, Yeşil Kapitalizm ya teşvik-ceza yöntemleriyle veya alternatif enerji endüstrilerinin karlı hale getirilmesiyle büyüme ekonomilerinin fosil yakıtlarından uzaklaştırılmasını öngörür. Buna mukabil Eko-Marksizm, kapitalizm ile fosil yakıtlarının birbirinden ayrılamayacağını, bu bağlantının bir tarihsel materyalizm unsuru ve medeniyetlerin üretim ilişkileri meselesi olduğunu söyler. ${ }^{46}$ Elmar Altvater, bunu bir ileri noktaya götürerek Batı medeniyeti için "fosil kapitalizmi” kavramını ortaya koyar. ${ }^{47} \mathrm{Bu}$ kavramın arkasında, Altvater' in, bugüne kadar fosil yakıtlara bağımlı ekonomiye yapılan yatırımlardan (bu yakıtları kullanan araç, bina ve fabrikalar) geri dönülemeyeceğine dönük düşüncesi yatmaktadır. Yeşil Kapitalizm ise, bu eleştiriye farklı bir özeleştiri ile cevap verir: kapitalizmin fosil yakıtlarına bağımlı olmasının sebebi bu kaynakların görece ucuz olması ve bu göreli ucuzluğun kapitalizm için varoluşsal bir öncelik olmasıdır. ${ }^{48} \mathrm{Bu}$ açıdan Yeşil Kapitalizm, daha ucuz ve verimli enerji formlarının ortaya çıkması veya (solar fotovoltaik teknolojide olduğu gibi) yatırımla daha verimli hale getirilmesiyle kapitalizmin fosil yakıtlarından vazgeçebileceğini dile getirir. Bu, daha önce bahsettiğimiz Falkner'ın minilteralizm kavramsallaştırmasına bir geri dönüş gerektirir. Falkner'ın argümanından yola çıkarak, kapitalizmin düşük karbonlu ekonomiye geçişi, kapitalizmi temsil eden en büyük şirketler nezdinde oluşturulacak küçük ve hızlı karar veren bir "iklim kulübünün” yaratılmasıyla mümkün olabilir. ${ }^{49}$ Kapitalizmin en güçlü temsilcileri, bu şekilde karbona bağımlı üretimlerini yenilenebilir enerjilere doğru çevirebilir ve kısa vadede bir eylem planı ortaya koyabilirler. Ancak burada tekrardan bir göreli mutlak kazanç problemi ortaya çıkar. Amerikan ve Çin firmalarının birbirleriyle küresel rekabet içinde oldukları bir dönemde bir grup etkili şirketin erken davranarak enerji kaynaklarını değiştirme yoluna gitmeleri, diğer şirketler tarafından suiistimal edilerek bedavacıllğg (free-riding) sebebiyet verebilir. Bu tekrardan neorealist açmazların başında gelen tutsak ikilemine evirilerek, yeni ve daha geniş çaplı bir iklim kurumsallaşmasına ihtiyaç bırakacaktır.

Yine de iklim tartışmaları bakımından Yeşil Kapitalizm'in ortaya çıkarak Eko-Marksizm'in eleştirilerine ciddi şekilde cevap vermeye çalışması, küresel iktisadi sistem açısından önemlidir. Kapitalizm içerisinde, karbon salınımına bağımlı büyüme-odaklı sistemin reformuna dönük bu tip bir akım çıkmasının uluslararası ilişkiler ile doğrudan bağlantısı vardır ve Yeşil Kapitalizm'in bu şekilde ortaya çıkışı üç ana başlıkta incelenebilir: artan enerji fiyatları, Ortadoğu'nun enerji jeopolitiği ve güvenliği, uluslararası anlaşmalarda Çin'in değişen rolü.

İlk olarak 2015-2016 itibariyle petrol ve doğalgaz fiyatları düşmüş olsa da, bundan önceki ve sonraki senelerle tamamen bir tezat içermektedir. ${ }^{50}$ Geçici bir petrol arz patlamasıyla düşen fiyatlar, petrole endeksli doğalgaz kontratlarının da fiyatını düşürmüş, tarihteki en ucuz seviyesine doğru çekmiştir. Ancak öngörüler, bu ucuzluğun geçici olacağını ve fiyatların yükselmesinden başka bir ihtimalin olmadığı konusunda hemfikirdir. Yükselen fosil yakıtı fiyatları, hem alternatif enerji kaynaklarının endüstrilerini daha rekabetçi hale getirirken, bu sektöre dönük altyapı yatırımını daha cazip kılmaktadır. Ortaya çıan tabloda, serbest piyasa ekonomilerinin, sürekli büyüme

46 Joel Kovel, "Why Ecosocialism Today?”, New Socialist, Cilt 61, 2007, s.10.

47 Elmar Altvater, “The Social and Natural Environment of Fossil Capitalism”, Social Register, Cilt 48, 2007.

48 Sian Sullivan, "Green capitalism, and the cultural poverty of constructing nature as service-provider", Radical Anthropology, Cilt 3, 2009, s.18-27.

49 Falkner, "A Minilateral Solution”, s.92.

50 “Short-term Energy and Summer Fuels Outlook", US Energy Information Administration, 12 Nisan 2016, https://www. eia.gov/forecasts/steo/report/prices.cfm, (Erişim Tarihi 26 Haziran 2016). 
için yenilenebilir enerji kaynaklarına yönelmesine ve uzun vadede bu tip kaynakları geniş ölçüde kullanılabilir hale getirmek için kaynak aktarmasına sebep olacaktır. ${ }^{51}$ Bu bağlamda da, küresel ekonomik büyüme için fosil yakıtlarının "olmazsa olmaz" olmadığı, finansal olarak daha avantajlı olduğu durumda yenilenebilir enerji kaynaklarına yönelimin bir kapitalist gereklilik olduğu yönünde bir konsensüs ortaya çıkacaktır. Bu düşünce, Eko-Marksizm'e bir karşı eleştiri olarak, karbon salınımını düşürmek için kapitalist sistemin yıkılmasına gerek olmadığını ve sistemin serbest piyasa üzerinden daha temiz kaynaklara geçebileceği savını ortaya koyar.

Yeşil Kapitalizm’i ortaya çıkaran diğer ikinci bir sebep da Ortadoğu jeopolitiği ve giderek problemli hale gelen bölgenin enerji güvenliğidir. Enerji güvenliği, arz ve talep güvenliğinin yanı sıra transit ve üretim güvenliğini de içerdiği için, askeri ve siyasi açıdan istikrarsız bölgelerde enerji sektörünün risk primi yüksektir. $^{52}$ Özellikle 2001 sonrasında Afganistan ve Irak’taki askeri müdahalelerin istikrarsızlı̆̆ devam ettirmesi, İran'la yaşanan uzun süreli krizle de birleşince, Ortadoğu'nun enerji kaynaklarını siyasi açıdan yüksek maliyetli hale getirmiştir. Bu çatışma daha bölgesel bir hal alarak bir tarafta İran, öbür tarafta Suudi Arabistan ve Katar’ı içeren ve mezhepsel arka planı olan bir sürekliliğe evirilmiştir. Suriye iç savaşının da alevlenmesiyle, Ortadoğu enerji güvenliği, büyük petrol ve doğalgaz üreticileri arasında uzun süreli bir anlaşmazlığa yol açmış, Yemen, Cibuti ve Birleşik Arap Emirlikleri gibi transit ülkeleri de içerisine çekmiştir. ${ }^{53}$ Ortadoğu'da devam eden istikrarsızlık ve bunun fosil yakıtı üreticilerine yansıması, konuyu uluslararası enerji güvenliği sorunu haline getirerek, bu bölgede üretilen kaynakların siyasal ve askeri açıdan daha yüksek maliyetli hale gelmesine sebep olmuştur. Bu durum, ABD'nin en üst düzey karar mekanizmalarında dile getirilen bir sorun halini almış, ünlü Profesör Bernard Lewis başta olmak üzere, bölgede barışın gelmesi için Amerikalıların daha az petrol tüketmesi gerektiğini öne süren geniş bir ortak aklın ortaya çıkmasına yol açmıştır. ${ }^{54} \mathrm{Bu}$ durumda, fosil yakıtlarına (özellikle petrolde) dönük bağımlılığın azaltılması, sadece iktisadi değil, politik ve stratejik bir hal almış, kapitalizm içerisinde devam eden "yeşilleşme" sürecini de siyasi açıdan hızlandırmıştır.

Üçüncü olarak, uluslararası anlaşmalarda Çin'in pozisyonu (özellikle bu makalenin odağı olan iklim değiş̧ikliği ve karbon salınımına dönük müzakereler) Yeşil Kapitalizmin ortaya çıkışına katkıda bulunmuştur. Daha önce de belirtildiği gibi, Kyoto Protokolü ve onu takip eden müzakereler, neorealist düzlemde konumlandırılabilecek bir dizi faktör sebebiyle başarılı olamamış, Paris İklim Anlaşmasına kadar belirlenen hedeflere ulaşamamıştır. Hem neoliberal kurumsalcilığın neorealizme karşı vermiş olduğu inandırıcı karşı argümanların hayata geçirilmesi, hem de Çin'in daha uyumlu bir pozisyona çekilebilmesi sonuçta Paris İklim Anlaşması başarısına yol açmıştır. Ancak Çin' in daha önceki pozisyonunu belirleyen fosil temelli büyüme modeli yerine, aynı oranda temiz ve yenilenebilir enerji teknolojileri ve altyapıları üreten bir Çin'in de ortaya çıkışı, bu pozisyon değişikliğinde önemlidir. ${ }^{55}$

51 Scott Nyquist, "Lower oil prices but more renewables: What's going on?”, McKinsey \& Company, Haziran 2015, http:// www.mckinsey.com/industries/oil-and-gas/our-insights/lower-oil-prices-but-more-renewables-whats-going-on, (Erişim Tarihi 26 Haziran 2016).

52 A. Skouloudis, A. Flamos ve J. Psarras, "Energy Supply Risk Premium: Review and Methodological Framework”, Energy Sources, Cilt 7, Sayı 1, 2012, s.71-80.

53 Laura el-Katiri, "Why Middle East conflict is a bigger threat to UK energy security than Putin", The Guardian, 5 Eylül 2014, http://www.theguardian.com/big-energy-debate/2014/sep/05/conflict-middle-east-energy-security-putin, (Erişim Tarihi 26 Haziran 2016).

54 Bernard Lewis, "What Went Wrong?", The Atlantic, Ocak 2002, http://www.theatlantic.com/magazine/ archive/2002/01/what-went-wrong/302387/, (Erişim Tarihi 26 Haziran 2016).

55 "By the Numbers: China’s Clean Energy Investments Show Big Strides”, Bloomberg, 3 Kasım 2015, http://www. bloomberg.com/news/articles/2015-11-02/by-the-numbers-china-s-clean-energy-investments-show-big-strides, (Erişim Tarihi 26 Haziran 2016). 
Çin'de petrol ve doğalgaz temelli bir altyapının ABD'de olduğu kadar eski ve derin çıkar ağları içermemesi $^{56}$, Çin'i petrol-sonrası üretim modeline geçişini kolaylaştıran bir faktördür. Bu açıdan bakıldığında, Çin'in büyümeye devam etmesi için üretimi dış tedarik (outsourcing) yoluyla sağlamaya geçmesi ve karbon temelli ekonomisinin hızla buluş ve teknoloji temelli ekonomiye geçirilmesi gerekmektedir. Bu geçişte başarılı olacak bir Çin devletinin politikaları, giderek daha artan oranda Avrupa'ya benzeyecek ve emisyon temelli üretimi daha güçsüz ve az gelişmiş ülkelere kaydırmasına sebep olacaktır. Bu eğilim de Yeşil Kapitalizmin ana önermesi için önemli bir veridir: mevcut serbest piyasa kuvvetleri Çin'in düşük karbonlu ekonomiye geçişine ve bu ülkenin yenilenebilir enerji kaynaklarının üretimi konusunda lider pozisyona geçmesine, dolayısıyla da uluslararası anlaşmalarda daha aktif ve yapıcı bir rol oynamasına sebep olacaktır. Sonuç olarak Paris İklim Anlaşmasında Çin ile beraber varılan nokta, Çin'in temiz enerji kaynaklarının üretimi ve kullanımı ile büyümesini devam ettirebileceği ve bu geçişten karlı çıkacağına dönük inancının da bir göstergesidir. Bahsedilen bu trend devam ederse, Çin önümüzdeki yıllar içerisinde küresel üretim normlarını Yeşil Kapitalist bir odağa doğru kaydırabilir.

Sonuç olarak Eko-Marksizm ve Yeşil Kapitalizm, karbon temelli bir büyüme modeline karşı farklı yapısal çözümler üreten iki okul olmuştur. Eko-Marksizm, küresel ısınmanın ancak kapitalizmin ortadan kalkmasıyla sağlanabileceğini öne sürerken, Yeşil Kapitalizm, mevcut serbest piyasa ivmelerinin karbona bağımlı olmayan bir büyüme modeline dönüştürülebileceğini iddia eder. Zira yenilenebilir enerji endüstrisi, giderek fosil yakıtı endüstrilerinden daha cazip ve finansal fizibilitesi kuvvetli bir alternatif olarak ortaya çıkmaya başlamıştır. Ancak Eko-Marksizm'in sınıfsal eleştirisi hala geçerlidir. Yeşil Kapitalizm, iklim meselesini uluslararası-iktisadi bir sorun olmaktan, bir sosyal sorun haline indirgemekte, fosil-temelli ekonomilerden yeşil ekonomilere geçişteki sosyal ve finansal yükün yine çalışan sınıf üzerine dayatılmasını öngörmektedir. Bu da Eko-Marksizm’e göre bir nevi “yeşil kemer sıkma" politikasına yol açacak, endüstri devriminin başında olduğu gibi geniş nüfus hareketleri ve direnişlerine yol açacaktır. Bu bağlamda Eko-Marksizm, Yeşil Kapitalizm’in iklim meselesini sadece bir uluslararası ilişkiler problemi olarak çözdüğünü, sınıfsal ve sosyal açıdan konuyu tamamıyla cevaplayamadığını öne sürer.

\section{Sonuç}

Paris İklim Anlaşması, enerji güvenliği ve iklim müzakereleri konusunda uzun süredir devam eden açmazı aşmış ve küresel bir çevre tehdidini, yine küresel bir işbirliği yoluyla çözme yoluna girmiştir. 1992 Rio Dünya Zirvesi ve 1997 Kyoto Protokolü’nden beri varılamayan bu anlaşmanın 2015 Paris İklim Anlaşması' yla sağlanabilmesi, uluslararası ilişkiler teorileri açısından da önemlidir. Bu makalede, neo-neo tartışmasının bu işbirliğine katkısı tartışılmış, bu tartışmanın ötesinde iklim ve çevre ile ilgili iki teori olan Eko-Marksizm ve Yeşil Kapitalizm de uluslararası ilişkiler teorileri bağlamında tekrardan konumlandırılmıştır. Paris İklim Anlaşması, neorealizmin özyardım, hayatta kalma, mutlak çıkar, anarşi ve sorumluluğu devretme gibi önemli tetkiklerinin, neoliberal kurumsalcllık tarafından iyi anlaşıldığını ve doğru çerçevelendirildiğini göstermektedir. Bu bağlamda neoliberal kurumsalcılık, neorealizmin ana eleştirilerine çoklu karşılıklı-bağımlılık, göreli çıkar ve konu-temelli uzlaşma ekseninde cevap vermiş, karbon salınımı konusunda yapılacak anlaşmanın, öncelikle enerji arz, talep ve transit güvenliğine bağlı olacağını öne sürmüştür. Neo-neo tartışması çerçevesinden bakıldığında, Paris İklim Anlaşması'nı başarılı kılan faktörlerin başında, karbon salınımı ve iktisadi büyüme

56 Liu Feng, Yu Hu, Chris Hall ve J. Wang, The Chinese Oil Industry History and Future, Londra, Springer Briefs in Energy, 2013. 
arasındaki ilişkinin iyi değerlendirilmesi ve ülkelere salınım azaltma konusunda tepeden yapılan baskılar yerine, ülkelerin bu azaltmayı gönüllü olarak yapmalarının önünün açılması gelmektedir. Bunun yanı sıra, kurumsal olarak belirlenen karbon salınımı azaltma yüzdelerinin Westphaliatemelli egemenlik anlayışıyla olan ilişkisi ve devletlerin (özellikle Çin'in) küresel çevre güvenliği ve egemenlik arasında kurabildikleri bağ da önemlidir. Tabi bu bağın kurularak uluslararası bir norma dönüşmesinde neoliberal kurumsalcılığın ana parametreleri belirleyici olmuştur.

Ancak bu makale, bir uluslararası ilişkiler teorik meselesi olan neo-neo tartışmasını iklim konusuna taşırken, iklim-siyaset ilişkilerindeki önemli yeni iki teori olan Eko-Marksizm ve Yeşil Kapitalizm'i uluslararası ilişkiler teorileri bünyesinde değerlendirmeye çalışmıştır. Bu açıdan EkoMarksizm, küresel ısınmayı hem bir sınıf çatışması olarak, hem de Wallerstein'ın "dünya sistem teorisi” perspektifi üzerinden bir merkez-çevre ilişkisi olarak açıklamıştır. Bu görüşe göre küresel ısınma, kapitalist ülkelerin hem sınıf temelli, hem de küresel merkez-çevre temelli mağduriyet ağları yaratmasına sebep olmuştur ve bu mağduriyetin giderilmesinin tek yolu kapitalist sistemin lağvedilmesidir. Marksizm'in küresel-ekolojik eleştirilerine uzun süre sessiz kalan kapitalist ve neoliberal literatür, petrol fiyatlarının düşmesi, Ortadoğu'da artan istikrarsızlık ve Çin'in iklim politikasını değiştirmeye başlamasıyla kendi içerisinden bir eleştirel akım çıkarmıştır. Yeşil Kapitalizm olarak kendisini ifade eden bu yeni akım, küresel ısınmanın durdurulması için kapitalizmin ortadan kaldırılmasına gerek olmadığını, serbest piyasa hareketlerinin zaten kapitalist ekonomileri karbon temelli büyüme rejiminden vazgeçirmeye başladığını iddia etmiştir. Buna göre Yeşil Kapitalizm'in, "kapitalizm ile küresel ısınma birbirini içeren faktörlerdir” eleştirisine verdiği cevap iktisadi verimlilik temelinde olmuş, temiz ve alternatif enerji kaynaklarının finansal olarak karlı hale getirilmesiyle birlikte, kapitalist ekonomilerin hızla karbon temelli büyüme modellerini bırakacağını ortaya koymuştur. Buna göre fosil yakıtlarına bağlı büyüme, bu kaynakların çıkar gruplarının siyasi çıkar ilişkilerine de bağlıdır. Doğal olarak bu, çıkar ilişkilerinin güçlü olduğu ABD'de temiz yakıtlara geçişi daha zorlaştırırken, ilişkilerin görece daha zayıf olduğu Çin'de ise daha kolaylaştıracaktır. Buradan hareketle Yeşil Kapitalist devrimin Çin'de başlayabileceği ve bu ülkenin temiz enerjilere yaptığı altyapı yatırımlarıyla, Avrupa Birliği ile beraber küresel fosil-sonrası büyüme modeline liderlik yapabileceği düşünülebilir. Eko-Marksizm'in Yeşil Kapitalizm'in bu önerisine dönük eleştirisi ise, sorunu devletler arası bir düzlemde çözdügünü sanarak meselenin sorumluluğunu yine sınıfsal ve merkez-çevre ayrılı̆̆ında bir yere attığıdır. Buna bağlı olarak büyük ekonomileri karbon temelli ekonomiden vazgeçirmek, hem finansal yükünü çalışan sınıfların çekeceği bir "yeşil kemer sıkma” politikasına dönüştürme anlamına gelecek, hem de bu ekonomilerin üretiminin karbona bağlı bölümünü daha zayıf ülkelere transfer etmesine yol açarak, yeni bir “yeşil gelişmiş” ve "yeşil gelişmemiş” ülkeler ayırımı yaratacaktır. 


\section{Kaynakça}

Altvater, Elmar. "The Social and Natural Environment of Fossil Capitalism”, Social Register, Cilt 48, 2007.

Barnett, Jon. "Security and Climate Change", Global Environmental Change, Cilt 13, No.1, 2003, s.7-17.

Bordiga, Amadei. “The human species and the Earth's crust”, Libcom, 15 Nisan 2012, https://libcom.org/ library/human-species-earths-crust-amadeo-bordiga, (Erişim Tarihi 26 Haziran 2016).

Bull, Hedley. The Anarchical Society: A Study of Order in World Politics, Londra, Macmillan, 1977.

"By the Numbers: China’s Clean Energy Investments Show Big Strides", Bloomberg, 3 Kasim 2015, http:// www.bloomberg.com/news/articles/2015-11-02/by-the-numbers-china-s-clean-energy-investmentsshow-big-strides, (Erişim Tarihi 26 Haziran 2016).

Catton, William R. Overshoot: The Ecological Basis of Revolutionary Change, University of Illinois Press, 1982.

Crawford, Robert M.A. Idealism and Realism in International Relations, New York, Routledge, 2001.

"Ebola: the failures of the international outbreak response", Medecins Fans Frontiers, 27 Ağustos 2014, http:// www.msf.org/article/ebola-failures-international-outbreak-response, (Erişim Tarihi 26 Haziran 2016).

Ehrlich, Paul. “The Population Bomb”. New York Times, 4 Kasım 1970, s.47.

El-Katiri, Laura. "Why Middle East conflict is a bigger threat to UK energy security than Putin", The Guardian, 5 Eylül 2014, http://www.theguardian.com/big-energy-debate/2014/sep/05/conflict-middle-east-energysecurity-putin, (Erişim Tarihi 26 Haziran 2016).

Falkner, Robert. "A Minilateral Solution for Global Climate Change? On Bargaining Efficiency, Club Benefits and International Legitimacy", Perspectives on Politics, Cilt 14, Sayı 1, Mart 2016, s.87-101.

Feng, Liu, Yu Hu, Chris Hall ve J. Wang, The Chinese Oil Industry History and Future, Londra, Springer Briefs in Energy, 2013.

Foster, John Bellamy ve Fred Magdoff, "Liebig, Marx and the Depletion of Soil Fertility: Relevance for Today's Agriculture”, Monthly Review, Cilt 50, Say1 3, 1998.

Gleick, Peter H. (der), Water in Crisis: A Guide to the World's Fresh Water Resources, Oxford University Press, 1993.

Grubb, Michael, Benito Müller ve Lucy Butler, "The Relationship between carbon dioxide emissions and economic growth", Oxbridge Study on CO2-GDP Relationships, Oxford, Şubat 2012, https://www. oxfordenergy.org/wpcms/wp-content/uploads/2011/02/Presentation19-The-RelationshipBetween CarbonDioxideEmissionsandEconomicGrowth-MGrubbBMullerLButler-2004.pdf, (Erişim Tarihi 26 Haziran 2016).

Haas, Peter M., Robert O. Keohane ve Marc A. Levy (der), Institutions for the Earth Sources of Effective International Environmental Protection, MIT Press, 1993.

Hardin, Garrett. “The Tragedy of the Commons”, Science, Cilt 162, No.3859, 1968, s.1243-1248.

Homer-Dixon, Thomas. "On the Environmental Changes as Causes of Acute Conflict”, International Security, Cilt 16, No.2, Sonbahar 1991.

Ilcan, Suzan. "Global Governing Organizations: Order-Building and Waste Management”, Current Sociology, Cilt 54, No.6, Kasım 2006, s.851-872

Kapitonenko, Mykola. “Resolving Post-Soviet 'Frozen Conflicts': Is Regional Integration Helpful?”, Caucasian Review of International Affairs, Cilt 3, No.1, Kış 2009, s.37-44.

Kennan, George F. “To Prevent a World Wasteland”, Foreign Affair, Cilt 48, Nisan 1970, s.401-413.

Keohane, Robert. (der), Neorealism and its Critics, New York, Columbia University Press, 1986.

Keohane, Robert O. After Hegemony: Cooperation and Discord in the World Political Economy, Princeton University Press, 1984.

Keohane, Robert O. ve Joseph S. Nye Jr., Power and Interdependence, Londra, Longman Classics, 2011. 
Kovel, Joel. “Why Ecosocialism Today?”, New Socialist, Cilt 61, 2007, s.10.

Krasner, Stephen D. (der), International Regimes, Ithaca, Cornell University Press, 1983. s.57.

Krasner, Stephen D. Structural Conflict: The Third World Against Global Liberalism, University of California Press, 1985.

Lewis, Bernard. "What Went Wrong?", The Atlantic, Ocak 2002, http://www.theatlantic.com/magazine/ archive/2002/01/what-went-wrong/302387/, (Erişim Tarihi 26 Haziran 2016).

Lipson, Charles. "International Cooperation in Economic and Security Affairs", World Politics, Cilt 37, 1984, s.1-23.

Liu, Zhu. “China's Carbon Emissions Report 2015”, Harvard Befler Center Reports, Mayıs 2015, http:// belfercenter.ksg.harvard.edu/publication/25417/chinas_carbon_emissions_report_2015.html, (Erişim Tarihi 26 Haziran 2016).

Meadows, Donella H., Jorgen Randers, ve Dennis L. Meadows. Beyond the Limits: Confronting Global Collapse, Envisioning a Sustainable Future, Chelsea Green Publishing Company, 1993.

Mearsheimer, John. The Tragedy of Great Power Politics, New York, W.W. Norton \& Company, 2001.

Milner, Helen. "The assumption of anarchy in international relations theory: A critique", Review of International Studies, Cilt 17, 1991, s.67-85.

Najam, Adil. "10 tests to find out if Paris's climate change deal is a success", The Guardian, 7 Eylül 2015, http:// www.theguardian.com/commentisfree/2015/dec/07/paris-climate-change-deal-summit-guide.

Napoli, Christopher. “Understanding Kyoto's Failure”, SAIS Review of International Affairs, Cilt 32, Sayı 2, 2002, s.183-196.

Newell, Peter ve Matthew Paterson, Climate Capitalism: Global Warming and the Transformation of the Global Economy, Cambridge, Cambridge University Press, 2010.

Nordhaus, William D. ve Joseph G. "Requiem for Kyoto: An Economic Analysis of the Kyoto Protocol." Yales Cowles Foundation Tartışma Bildirisi, Ekim 1998.

Nyquist, Scott. “Lower oil prices but more renewables: What's going on?”, McKinsey \& Company, Haziran 2015, http://www.mckinsey.com/industries/oil-and-gas/our-insights/lower-oil-prices-but-more-renewableswhats-going-on, (Erişim Tarihi 26 Haziran 2016).

O'Connor, James. "Capitalism, Nature, Socialism: A Theoretical Introduction”, Capitalism, Nature, Socialism, Cilt 1, Sayı 1, 1988, s.11-38.

Orme, John. "The utility of force in a world of scarcity", International Security, Cilt 22, No.3, 1997, s.138 - 167.

Oye, Kenneth. "Explaining Cooperation under Anarchy: Hypotheses and Strategies", World Politics, Cilt 38, 198, s.16-18.

Prates, Marcelo Madueiraj. "Why Prudential Regulation Will Fail to Prevent Financial Crises. A Legal Approach”, Working Paper 335, Banco Central Do Brasil, 2013, http://www.bcb.gov.br/pec/wps/ingl/ wps335.pdf, (Erişim Tarihi 26 Haziran 2016).

Prins, Gwyn vd. The Hartwell Paper: A New Direction for Climate Policy After the Crash of 2009, Institute for Science, Innovation and Society, University of Oxford, Mayıs 2010, http://eprints.lse.ac.uk/27939/1/ HartwellPaper_English_version.pdf, (Erişim Tarihi 26 Haziran 2016).

Ruggie, John. "Multilateralism: The Anatomy of an Institution”, International Organization, Cilt 46, No.3, 1992.

Russett, Bruce M. International Regions and the International System: A study in political ecology, Rand McNally, 1967.

Sassen, Saskia. "Territory and Territoriality in the Global Economy”, Journal of Human Values, Cilt 15, Sayı 2, Haziran 2000, s.372-393.

"Short-term Energy and Summer Fuels Outlook", US Energy Information Administration, 12 Nisan 2016, https://www.eia.gov/forecasts/steo/report/prices.cfm, (Erişim Tarihi 26 Haziran 2016). 
Skouloudis, A., A. Flamos ve J. Psarras, "Energy Supply Risk Premim: Review and Methodological Framework”, Energy Sources, Cilt 7, Sayı 1, 2012, s.71-80.

Steffen, Will, Paul J. Crutzen ve John R. McNeill. “The Anthropocene: Are Humans Now Overwhelming the Great Forces of Nature", AMBIO: A Journal of the Human Environment, Cilt 36, No.8, 2007, s.614-621.

Stein, Arthur A. "Neoliberal Institutionalism", Christian Reus-Smit and Duncan Snidal. (der), The Oxford Handbook on International Relations, New York, Oxford University Press, 2008, s.201-221.

Sullivan, Sian. "Green capitalism, and the cultural poverty of constructing nature as service-provider", Radical Anthropology, Cilt 3, 2009, s.18-27.

Susskind, Lawrence E ve Saleem H. Ali, Environmental Diplomacy: Negotiating More Effective Global Agreements, Oxford University Press, 2014.

“The Global Nuclear Nonproliferation Regime”, Council on Foreign Relations, 25 Haziran 2013, http://www.cfr. org/nonproliferation-arms-control-and-disarmament/global-nuclear-nonproliferation-regime/p18984, (Erişim Tarihi 26 Haziran 2016).

Waever, Ole. "Rise and Fall of the Inter-Paradigm Debate", Steve Smith, Ken Booth ve Marysia Zalewski. (der), International Theory: Positivism and Beyond, Cambridge, Cambridge University Press, 1996.

Wallerstein, Immanuel. "The West, Capitalism, and the Modern World-System”, Review, Cilt 15, Say1 4, 1992, s.561-619.

Walt, Stephen M. Origins of Alliances, Cornell University Press, Ithaca, 1987.

Waltz, Kenneth. "Realist Thought and Neorealist Theory", Journal of International Affairs, Cilt 44, No.1, 1990, s.21-37.

Wendt, Alexander. "Anarchy is what States Make of it: The Social Construction of Power Politics", International Organization, Cilt 46, Sayı 2, 1992, s.391-425.

Westing, Arthur H. (der.), Cultural Norms, War and the Environment, Oxford University Press, 1988.

Yamin, Farhana ve Joanna Depledge, The International Climate Change Regime A Guide to Rules, Institutions and Procedures, Cambridge University Press, 2004. 